\title{
Perennial Notes in Emily Dickinson's Poetry
}

\section{Dr. Abdul Wahab Siddiqui}

Asst. Professor \& HoD

Department of English, MAJ University, Rampur UP (India)

E-mail: abdulwahabsiddiqui@gmail.com

\begin{abstract}
:
Abstract American literature had a long period of apprenticeship. The nineteenth century American poetry has been represented by the three great poets- Ralph Waldo Emerson, Walt Whitman and Emily Dickinson. Emily was one of the great poets of all time, perhaps, the greatest of all American women poets. She wrote about 1800 poems, only seven of which were published during her lifetime, five of them in the Springfield Republican. Though she was not a philosopher, nor even a consistent thinker, she strikingly illuminated hidden recesses in the human soul. Themes and imagery of her poems are borrowed from ordinary life Amherst of her time, her father's influence, the loss of her near and dear ones, and the ordinary things around her like. Even a cursory glance at her themes reveals an extreme preoccupation with the reality of God, the possibility of faith, the effect of death, the problems of immortality, the nature of the soul, love, passion, pain, social scene and nature.
\end{abstract}

Keywords: Poetry, God, Death, Immortality, Love, Nature

\section{$\underline{\text { Introduction }}$}

The American writers from colonial times until now have written countless essays and songs, short stories and novels, plays and poems. Narrative poetry, not of very high quality has been written from the days of the New Englanders to the present. This same pace is found in Modern Poetry. Lyrical poetry has been abundantly written by Sidney Lanier and E. A. Poe. The nineteenth century American poetry has been represented by the three great poets- Ralph Waldo Emerson, Walt Whitman and Emily Dickinson.

Emily Dickinson, a major American poet, a recluse, nicknamed the 'Nun of Amherst' was born on December 10, 1830 in Amherst, Massachusetts. She was the second child of Emily Dickinson and Edward, the treasurer of the college and leading citizen of the town. Emily's grandfather, a lawyer by profession, devoted his life to the advancement of Christianity and bequeathed to his family the responsibilities of that cause. The father's practice along with the obligations to church and college was inherited by his son, Edmund. By the time of Emily's birth, the Puritan Theocracy had made its last stand and its foundations were tottering. Yet in 1830, Amherst was still a Puritan village with its life centred in the church and college, controlled by the church. Of Emily's childhood very little is known. Emily 
Journal of Advance Research in Science and Social Science (JARSSC)

Official Publication of Indian Mental Health \& Research Centre

DOI: $10.46523 /$ jarssc.04.01.03

Multidisciplinary, Open Access
ISSN: 2582-2004

Volume 04, Issue 01

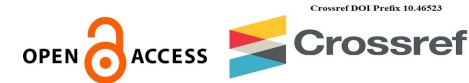

attended Amherst Academy and Mount Holyoke Female Seminary at South Hadley. Though a good student, Emily dreaded examinations and exhibitions. She had no inclination to display her talents in public. She grew up in a secure, well-ordered family, with a father deeply concerned for his children's welfare. To Emily, her father was so important that without him, her personality cannot be properly interpreted. His gods were her gods. His granite integrity was hers also. As a child she stood in no little awe of him. She herself exclaimed for the strict conservative nature of her father: "If father is asleep on the lounge, the house is full." (Poems by Emily Dickinson, 6) But defiance of her father was the defiance of what was deepest in her, an instinct of righteousness that could not be denied. She came to understand and respect her father as her own soul. She had known other prominent and brilliant men but none to match her father. She wrote after his death that his heart was pure and terrible and perhaps no other like it existed. Emily's father was a firm moralist, reserved in manners and had a marked individuality in thought and love of independence: "When he spoke, his timid wife trembled, obeyed and was silent." (The American Tradition in Literature, 1010-1011)

Emily was probably guilty of her slight figure, was reticent and avoided photographs. Some biographers attribute this indifference to her lack of good features. The only known photograph of Emily dates from the Mount Holyoke period. The dominant impression is that of an unformed, sensitive girl whose large eyes unflinchingly challenge the viewer. These impressive brown eyes and thick auburn hair drawn back tightly were the only good features in an otherwise plain freckled face. She called herself the 'only Kangaroo among the Beauty' and noted that she was "small like the wren, and my hair is bold, like the Chestnut Bur-and my eyes, like the Sherry in the Glass, that the Guest leaves.” (Emily Dickinson, 17)

Emily completely withdrew herself from social contact and remained unmarried throughout her life. She lived the life of a recluse, perfectly devoid of outward event, remained unknown during her life time. Her sister, Lavinia was a lifelong companion and trusted confidante. Other than Lavinia, she was attached to her family and very few people only. She did not at once become a recluse. It is not just clear when Emily began to dress invariably in white and to invert herself in an atmosphere of hallowed mystery that her garments symbolized. By 1862, her seclusion had become marked but not absolute. By 1870, her seclusion had become 
Journal of Advance Research in Science and Social Science (JARSSC)

Official Publication of Indian Mental Health \& Research Centre

DOI: $10.46523 /$ jarssc. 04.01 .03

Multidisciplinary, Open Access
ISSN: 2582-2004

Volume 04, Issue 01

a conscious resolution, "I do not cross my father's ground to any house or town." (Thematic Patterns of Emily Dickinson's Poetry, 9) For the last fifteen years of her life the village knew Emily only as a white figure flitting about the garden in the summer dust. Friends of the family thought her as an exquisite touch me not and considerably avoided any intrusion on Miss Dickinson's privacy.

The life of seclusion that she later led ostensibly does not mean a life of inactivity. During her life of seclusion, Emily became more and more absorbed in writing poetry. Dickinson's Poetry Emily was one of the great poets of all time, perhaps, the greatest of all American women poets. She wrote about 1800 poems, only seven of which were published during her lifetime, five of them in the Springfield Republican. First edition of her poetry was published in 1890, edited by Mabel Loomis Todd and Thomas W. Higginson. The complete edition of her poems was published in three volumes by Thomas H. Johnson in 1955 . There are no titles given by Dickinson to her poems. In the anthologies the arrangement is chronological and classification was based principally on key words in the poems themselves. In 1862, the thirty-one years old Emily wrote a letter to Thomas Wentworth Higginson, a writer and reformer, enclosing four of her poems- 'Safe in their Alabaster Chambers', 'I'll tell you how the Sun rose', 'The nearest Dream recedesunrealised' and 'We play at paste. The second letter to Higginson, written ten days later, enclosed three poems: 'South Winds jostle them', 'Of all the sounds dispatched abroad' and 'There came a day at Summen's full'. All these poems reveal that in 1862 the poet was no longer novice but an artist whose strikingly original talent was fully developed. "Poetry seems to flow out of her involuntarily like a mountain rill." This is absolutely true in case of Dickinson. Though she was not a philosopher, nor even a consistent thinker, she strikingly illuminated hidden recesses in the human soul.

Her perception of beauty is so keen that she sees it even in a locomotive. A poet of romantic sensibility, Emily's sensitive soul throbbed to the ray of light in winter, to the song of oriole and to the thousand little things that made her world glow with beauty. Themes and imagery of her poems are borrowed from ordinary life and the ordinary things around her. Amherst of her time was a thicklywooded small town and was equity rules away from Cambridge and Boston. In Amherst, relaxation was limited to simple social visits and family exchanges. Cards, dancing and novel reading were still prohibited in 1830. The town's insular complacency and habitual fondness for gossip could be stifling and even cruel. This was 
Journal of Advance Research in Science and Social Science (JARSSC)

Official Publication of Indian Mental Health \& Research Centre

DOI: $10.46523 /$ jarssc.04.01.03

Multidisciplinary, Open Access
ISSN: 2582-2004

Volume 04, Issue 01

Amherst, with its limitations and strengths reflected in Emily Dickinson's poetry. As George Whicher has succinctly phrased it in this was a Poet: "To an extraordinary degree she absorbed into herself the atmosphere of the countryside where she was born. . . she made it her business to embody in her poems the quintessence of New England ways of thinking and feeling. In her the region became articulate.” (Emily Dickinson, 9) Nature has been one of the most recurring themes of English and American poetry since the closing decade of the eighteenth century. The chief exponent of this subject, William Wordsworth penetrated beneath the outward manifestation of nature, explored its utmost philosophical limits and gave to her a separate life and soul of her own.

The highly sensitive and creative mind of Emily must have definitely been influenced by the nature poetry of Wordsworth. She, while sitting in her little solitary world, at the window pane, observed every minute object of nature with her keen power of observation and gave an outlet to her microscopic power of imagination. She wrote more than 500 poems on nature. To her, Nature appears as the gentlest mother, very affectionate, loving and care taking soothing and comforting her bruised children. A minute observer of Nature as Dickinson was, nothing of Nature escaped her notice. The common objects of nature like sunrise, sun-set, birds, flowers, changes in the season, the magical movement of the rotation of day and night, wind and the storm fascinated and stirred her imagination and filled her with exultation and immense pleasure. Her unique approach to the external beauty of nature, the power of storms, the strangeness of creation, the fleeting aspects of the material, and the mystery of the seasonal process fully demonstrate that even the most neglected and hackneyed subjects can be revitalized by genius.

If Emily Dickinson loved external nature and faithfully recorded her impressions of it, she was even more fascinated by the complex social scene around her. She responded to the interplay of community events and human personality, meditated on friendship, and closely examined her own deep experience of love and passion. Apart from the poems written on the theme of Nature and social scene, she wrote more than a hundred poems on the theme of love. An overwhelming majority of them were written during the years 1861-1863. Emily, being an introvert type of personality, never wished her romance to be probed. About her love crisis, so many impossible and exaggerated stories have been fabricated that one almost 
Journal of Advance Research in Science and Social Science (JARSSC)

Official Publication of Indian Mental Health \& Research Centre

DOI: 10.46523 jarssc. 04.01 .03

Multidisciplinary, Open Access
ISSN: $2582-2004$

Volume 04, Issue 01

despairs of ever identifying the man. The identification of her lover has beguiled biographers and readers for generations, but his identity still remains uncertain. However, the Reverend Charles Wadsworth, whose death on April 1, 1882, caused her to comment, "Love has but one Date-'The first of April' 'Today, Yesterday, and Forever,"” is most generally considered to be the man. Emily's own experience of passion occasioned most of her love poetry, but she also considered the subject from a philosophical view-point. The extravagance of her feelings about love's importance caused her to remark that "love is all there is" and to equate it with God himself. Because love was meaningless unless reciprocated, she felt that God was dependent upon man's love for complete happiness. As she matured, she realized that love created the only harmony in the universe and that divine love surpassed nature's beauty and human affection. Love triumphs over both life and death to achieve an almost divine status.

Few of her poems on the subject have literary merit and the main exception is

The Soul selects her own Society,

Then shuts the Door.

To her divine Majority

Present no more.

I've known her from an ample nation

Choose One,

Then close the valves of her attention

Like Stone.

The keynote in the above poem is that to a life of humdrum routine, she preferred the life in the world of her imagination where she could love with greater fullness and intensity. This poem has some relation to her choice of a life of solitude, made about this time, preferring her own circle and closing the door on the general world, as the opening lines of the poem suggest. A surface reading of the poem categorizes it into a simple love poem suggesting future suitors being rejected because of the 'chosen one' rather than the temptations of society that might distract her from her art. While on the other hand, "One" may be the Supreme God and finally this is the hint of nunnery, where she waits for God alone. Unlike most other American poets, she was religiously oriented. With a great spirit of religious unorthodoxy, Dickinson relies more on her soul to lead her to Heaven and to God than all the 
Journal of Advance Research in Science and Social Science (JARSSC)

Official Publication of Indian Mental Health \& Research Centre

DOI: 10.46523 jarssc. 04.01 .03

Multidisciplinary, Open Access
ISSN: $2582-2004$

Volume 04, Issue 01

sermons and church-goings that conventional religion recommends. Her written comments show how distressed she was by the religious pressures.

In fact she discarded the sway of religion and relied more on intuition and imagination. She could not accept the harsh dogmas of innate depravity, arbitrary election and predestination, or revere the Bible as true history and the only moral guide for man. In other words she rejected all that made man insignificant and helpless before the crushing force of God. But in spite of her scornful attitude to the traditional picture of the Puritan's God, we find in her true pity and a deep faith in Heaven and Immortality. Even a cursory glance at her themes reveals an extreme preoccupation with the effect of death, the nature of the soul, the problems of immortality, the possibility of faith, and the reality of God. Certainly in the sense that she sought the essential moral truths veiled behind material appearances and strove to experience and perceive the Divine force (or as she phrased it "Circumference") she was mystically inclined. Even God himself, she felt, was dependent on human love for complete happiness. Mainly she accepted God as the omnipotent ruler and respected the supreme majesty of his person.

Despite her wavering and doubts, she retained her personal belief. If human love and spiritual bliss were one side of life's coin, the reverse showed pain and loss or death. For Emily Dickinson as for Hawthorne and James, the knowledge of pain became a touchstone for estimating the depth of a human soul. Primarily she notes that true pain becomes such an essential part of one's being that its departure causes a deeper loneliness in the soul. Since pain's intensity is unrelenting, one can never master it, nor even hope for time to assuage its power. Yet pain has value, since it provides the victim with enlightenment to a 'larger pain'. That is, from a personal experience of grief one comes to the realization of its universal human condition. Thus, it greatly strengthens man, enabling him to bear increased stresses and survive as a human. Death is one of the perennial themes of Dickinson's poetry.

Dickinson's' large new house was close to the centre of town and beside a cemetery. Funeral processions usually passed the Dickinson house on the way to the cemetery, and it is small wonder that Emily grow up conscious of death- it was impossible to avoid. Later watching a close friend of hers nearing death, she was so moved by the strange beauty of the dying girl that friends had to lead her away. The event so weighed upon her impressionable, thirteen- 
Journal of Advance Research in Science and Social Science (JARSSC)

Official Publication of Indian Mental Health \& Research Centre

DOI: $10.46523 /$ jarssc. 04.01 .03

Multidisciplinary, Open Access
ISSN: 2582-2004

Volume 04, Issue 01

year old mind that she became sick, and only a prolonged visit to Boston dulled the traumatic experiences. At twenty-one she rather morbidly pictures her own death: "The other day I tried to think how I should look with my eyes shut, and a little white gown on, and a snowdrop on my breast; and I fancied I heard the neighbors stealing in so softly to look down in my faceso fast asleep- so still. . . .I think of the grave very often, and how much it has got of mine, and whether I can ever stop it from carrying off what I love." (Emily Dickinson, 13) Later she saw the death of all those; her father, her mother and Ben Newton, who were the shaking influences of her life. The traumatic effect of these deaths made her profounder, more grimly thoughtful and more philosophically aware of "Death" as a perplexing and puzzling phenomenon of life. Death remained throughout her life an over-mastering obsession.

The five hundred and odd poems which deal with death, occupy a central place in the corpus of her poetry. No doubt, death has been a fascinating subject for other poets also but Dickinson has looked at it from various angles and described it in a poetic idiom of her own "She died all her life". She has drawn a disturbing portrayal of death in the following poem: I felt a funeral in my Brain And Mourners to and fro Keep treading-treading-till it seemed That sense was breaking through (280) The detailed presentation of a complete funeral as felt through the ebbing sensations of a dead person borders on the morbid in depicting the terrible struggle that the separation of the body from the soul occasions. In this poem, there is no hope of immortality. It depicts a despairing plunge into an eternal abyss.

In yet another poem, Emily visualized Death as a person she knew and trusted. This person might be any person from Amherst, or any tutor, minister of lawyer, whom she knew and with whom she exchanged valentines and who at one trial or another had acted as her lover, well-wisher:

Because I could not stop for Death

He kindly stopped for me

The Carriage held, but just ourselves And Immortality (712)

In this poem, instead of the human fear or religious awe usually associated with death, it is portrayed as a restful trip, a pleasant journey with a courteous visitor and an unnoticed third traveller, immortality.

One is startled to hear awesome death addressed as a kindly gentleman whose gracious manner soothes the victim and whose invitation is gladly accepted as from an old family 
Journal of Advance Research in Science and Social Science (JARSSC)

Official Publication of Indian Mental Health \& Research Centre

DOI: 10.46523 jarssc. 04.01 .03

Multidisciplinary, Open Access
ISSN: $2582-2004$

Volume 04, Issue 01

friend or lover. Just as Death is the gateway to Immortality, in the same way, the death poems of Dickinson end only to usher in a new phase in her poetical career. The dominant mood of this phase is a searching enquiry into the belief of Immortality, its nature and the necessity of such a belief as a Corollary to death. The spiritual and intellectual forces that shaped Dickinson's thinking were the Puritan tradition into which she was born and the transcendental and romantic doctrines that were prevalent in the New England of her youth. In her thoughts on Immortality, we find the streaks of transcendentalism as shaped by the ancient Hindu faith in the transmigration of soul running through the Biblical love which forms the background of her religious culture. Her belief in immortality is not free from doubts and she has freely expressed these doubts in several of her poems.

\section{CONCLUSION}

Among outstanding American writers few had to wait as long for critical and scholarly acceptance as did Emily Dickinson. With just seven poems published in her lifetime, it was not until the 1950s that she was securely placed with Poe and Whitman as a major poet. Today, she is regarded as a major American poet, and the greatest woman-poet in the English language. Basically she was a religious poet whose concern with the fundamental issues of death, pain, love, and immortality occasioned her finest lyrics. Undoubtedly, the areas of life and nature that most interested her were narrow and personal. Still, she probed these subjects deeply and produced a surprising variety of insights about external nature, the inner struggles of the human soul, and the mysteries of death and immortality. Her poems do not belong to the literature of escape. She confronted all the facts of life that came within her experience seeking to record all she could learn, ecstasy or anguish, and stating her conclusions without palliation. She defies labels: Romantic, Transcendentalist, Metaphysical, Meditative; she defies boundaries; she defies categories religious, lyric, or nature poet. She is something of all these or more. But there is no doubt about her uniqueness and individuality. Like only the greatest she stands alone. Her place is among those whose gifts are too intrinsic for renown.

\section{REFERENCES}

Bianchi, Martha Gilbert Dickinson, and Alfred Leete Hampson, editors. Poems by Emily Dickinson. LaVergne, TN, Lightning Source Inc., 2009. 
Journal of Advance Research in Science and Social Science (JARSSC)

Official Publication of Indian Mental Health \& Research Centre

DOI: $10.46523 /$ jarssc.04.01.03

Multidisciplinary, Open Access
ISSN: 2582-2004

Volume 04, Issue 01

Bradley, Sculley. The American Tradition in Literature. New York, Random House, 1981. 3.

Johnson, Thomas H. Emily Dickinson: An Interpretive Biography. Cambridge: Harvard

University Press, Belknap Press, 1955.

Pickard, John Benedict. Emily Dickinson: An Introduction and Interpretation. New York, Holt, Rinehart and Winston, 1967.

Reeves, James. Selected poems of Emily Dickinson. London, Heinemann, 1959.

Tandon, Neeru, and Anjana Trivedi. Thematic Patterns of Emily Dickinson's Poetry. New Delhi, Atlantic Publishers \& Distributors, 2008. 